\title{
ESTIMASI EFISIENSI TEKNIS DAN EKONOMIS USAHATANI KEDELAI (Glycine max L.) PADA LAHAN SAWAH
}

\author{
Oleh \\ HENDAR NURYAMAN \\ Fakultas Pertanian Universitas Siliwangi Tasikmalaya \\ e-mail: hendarnuryaman@unsil.ac.id
}

\begin{abstract}
Abstrak
Bertambahnya populasi penduduk Indonesia, peningkatan pendapatan perkapita dan kesadaran masyarakat akan gizi makanan serta kebutuhan akan industri pangan dan pakan yang berbahan baku kedelai, dimasa mendatang proyeksi permintaan akan kedelai terus meningkat. Hanya sekitar 35 persen dari total kebutuhan yang dapat dipenuhi dari produksi dalam negeri. Keadaan ini tidak dapat dibiarkan terus-menerus, mengingat potensi lahan cukup luas, teknologi, dan sumberdaya lainnya cukup tersedia. Untuk menekan laju impor kedelai dapat diupayakan melalui berbagai strategi diantaranya peningkatan produktivitas, perluasan areal tanam dan peningkatan efisiensi pada faktorfaktor produksi. Penelitian ini bertujuan untuk mengetahui (1) Pengaruh faktor-faktor produksi secara terhadap produksi usahatani kedelai, (2) Efisiensi faktor-faktor produksi secara teknis dan ekonomis pada usahatani kedelai, dan (3) Estimasi penambahan atau pengurangan faktor-faktor produksi. Penelitian dilakukan di Kecamatan Banjarsari Kabupaten Ciamis. Metode yang digunakan adalah survai eksplanatory (Explanatory survey). Penarikan sampel menggunakan teknik penarikan sampel berstrata dengan jumlah ukuran sampel sebanyak 97 orang. Data dianalisis menggunakan fungsi produksi Cobb-Douglass dan pendekatan fungsi produksi frontier. Hasil penelitian menunjukkan pengaruh penggunaan faktor produksi secara teknis, dimana lahan, benih dan tenaga kerja berpengaruh terhadap produksi pada lahan luas dan lahan sedang, pupuk organik hanya berpengaruh pada lahan luas. Pada lahan sempit, hanya faktor produksi lahan yang berpengaruh terhadap produksi. Secara ekonomis, analisis simultan variabel yang diamati baik itu pada lahan luas, sedang maupun pada lahan sempit berpengaruh nyata terhadap produksi. Sedangkan secara parsial pada lahan luas dan lahan sedang variable lahan, benih dan tenaga kerja berpengaruh nyata. Sedangkan pada lahan sempit, variabel lahan, urea, KCL dan tenaga kerja berpengaruh nyata terhadap produksi usahatani kedelai. Tingkat efisiensi secara teknis pada lahan luas, sedang dan sempit sudah mencapai tingkat yang efisien. Secara ekonomis pada lahan luas, sedang dan sempit tidak ada faktor produksi yang tepat efisien atau NPMXi/PXi=1. Faktor-faktor produksi kebanyakan berada pada kondisi yang tidak efisien baik itu pada lahan luas, sedang maupun sempit, dengan kata lain penggunaannya terlalu berlebihan sehingga perlu dikurangi.
\end{abstract}

Kata kunci: kedelai, faktor produksi, efisiensi

\section{PENDAHULUAN}

Kedelai merupakan tanaman pangan terpenting ketiga setelah padi dan jagung. Komoditas ini kaya akan protein nabati yang diperlukan untuk meningkatkan gizi masyarakat, aman dikonsumsi, dan harganya murah. Kebutuhan kedelai terus meningkat seiring dengan meningkatnya permintaan untuk bahan industri pangan seperti tahu, tempe, kecap, susu kedelai, tauco dan snack. (Marwoto dan Hilman, 2005). Di masa mendatang proyeksi permintaan kedelai akan terus meningkat seiring dengan meningkatnya konsumsi kedelai oleh masyarakat Indonesia mengingat beberapa pertimbangan seperti bertambahnya populasi penduduk, peningkatan pendapatan per kapita, kesadaran masyarakat akan gizi makanan. (Marwoto dan Hilman, 2005). Konsumsi per kapita dari $8,12 \mathrm{~kg}$ pada tahun 2005 menjadi 9,46 kg pada tahun 2020 . atau meningkat rata-rata 1.02 persen per tahun, hanya sekitar 35 persen dari total kebutuhan yang dapat dipenuhi dari produksi dalam negeri. Keadaan ini tidak dapat dibiarkan terusmenerus, mengingat potensi lahan cukup luas, teknologi, dan sumberdaya lainnya cukup tersedia. (Marwoto dan Hilman, 2005).

Badan Pusat Statistik (2006) menunjukkan, produksi kedelai menurun tajam dengan laju rata-rata $-1,65$ persen pertahun, penurunan produksi disebabkan oleh terus berkurangnya luas areal panen. Tanpa perluasan areal tanam, upaya peningkatan produksi kedelai sulit dilakukan karena laju peningkatan produktivitas 


\section{AIMBAR \\ Agribisnis}

ISSN 2460-4321

Volume 1・Nomor 2・Januari 2016

berjalan lambat, apalagi bila harga sarana produksi tinggi dan harga produk rendah.

Heriyanto et al. (2004), sumber pertumbuhan produksi kedelai melalui perluasan areal mencapai 2,71 juta ha, dengan rincian lahan sawah 1,42 juta ha dan lahan kering 1,29 juta ha. Dibandingkan dengan lahan kering, lahan sawah memiliki potensi yang lebih besar dalam mendukung peningkatan produksi kedelai.

Dalam pelaksanaan proses produksi pada suatu usahatani, petani dihadapkan pada masalah intern dan ekstern, masalah intern diantaranya keterbatasan faktor produksi, baik kualitas maupun kuantitas. Dengan demikian petani harus pandai memilih dan mengkoordinasikan jenis-jenis tanaman yang menguntungkan serta mengkombinasikan faktor produksi yang ada sehingga dapat menghasilkan pendapatan yang maksimal. Sedangkan masalah ekstern adalah kondisi alam atau musim serta serangan hama dan penyakit.

Berdasarkan uraian tersebut maka penelitian ini bertujuan untuk mengetahui :

1. Pengaruh penggunaan faktor-faktor produksi secara bersama-sama (simultan) dan secara sendiri-sendiri (parsial) terhadap hasil produksi pada usahatani kedelai.

2. Efisiensi penggunaan faktor-faktor produksi baik secara teknis maupun ekonomis pada usahatani kedelai.

3. Estimasi penambahan atau pengurangan faktor-faktor produksi baik secara teknis maupun ekonomis.

\section{TINJAUAN PUSTAKA}

Usahatani adalah himpunan dari sumbersumber alam yang terdapat di tempat itu yang diperlukan untuk produksi pertanian seperti tumbuhan, tanah dan air, perbaikan-perbaikan yang telah dilakukan di atas tanah, dan sebagainya. Mosher dalam Mubyarto (1995) menyatakan bahwa sebuah usahatani adalah sebagian dari permukaan bumi dimana seorang petani, sebuah keluarga tani atau badan usaha lainnya bercocok tanam atau memelihara ternak (Suratiyah, 2006).

Soekartawi (2003), menyatakan bahwa dalam proses produksi diperlukan kombinasi faktor-faktor produksi secara sekaligus yaitu tanah, modal, tenaga kerja, pupuk, benih, pestisida, serta manajemen. Faktor produksi sering pula disebut dengan "korbanan produksi", karena faktor produksi tersebut "dikorbankan" untuk menghasilkan produksi.

Beberapa hasil penelitian Sahara dan Sahardi (2005) menunjukkan bahwa luas lahan, pupuk anorganik dan pupuk organik berpengaruh positif, sedangkan fungisida berpengaruh negatif terhadap produksi kedelai. Sementara hasil penelitian Sri Sulastri (2011) mengenai kedelai pada lahan sawah adalah faktor produksi luas lahan, bibit, tenaga kerja pria dan wanita berpengaruh positif terhadap produksi, sementara pupuk anorganik, pupuk organik dan obat-obatan berpengaruh negative terhadap produksi.

Hasil analisis yang dilakukan oleh Abdul Gaffar Tahir (2010) menunjukkan bahwa secara teknis faktor-faktor yang mempengaruhi peningkatan produksi kedelai adalah tingkat pengalaman petani, jumlah angkatan kerja dalam keluarga, jumlah pupuk urea, jumlah pupuk $\mathrm{KCl}$, jumlah pupuk organik, status kepemilikan lahan sistem bagi hasil, varietas kedelai (varietas unggul), jarak tanam dan tipe lahan. Selanjutnya hasil penelitian Elys Fauziyah (2007), menyatakan secara teknis faktor produksi luas lahan, tenaga kerja dan bibit berpengaruh terhadap produksi kedelai sedangkan pupuk urea dan pestisida tidak berpengaruh.

Berdasarkan uraian di atas, maka diajukan hipotesis penelitian sebagai berikut: Penggunaan faktor produksi lahan, benih, pupuk anorganik (urea, SP-36, KCL), pupuk organik, pestisida dan tenaga kerja diduga berpengaruh terhadap hasil produksi usahatani kedelai baik secara simultan maupun secara parsial. Rata-rata penggunaan faktor-faktor produksi diduga belum efisien terhadap usahatani kedelai.

\section{METODE PENELITIAN}

Penelitian dilaksanakan di Kecamatan Banjarsari Kabupaten Ciamis dengan menggunakan metode survey eksplanatory (Explanatory Research), Menurut Juwono (2009), survey eksplanatori adalah pengamatan atau penyelidikan yang kritis untuk mendapatkan keterangan yang baik dan rinci terhadap suatu persoalan tertentu pada lokasi tertentu yang dilakukan untuk menyoroti hubungan antara variabel-variabel penelitian 


\section{Estimasi Efisiensi Teknis dan Ekonomis Usahatani Kedelai \\ (Glycine max L.) Pada Lahan Sawah \\ HENDAR NURYAMAN}

dan menguji hipotesis yang telah dirumuskan sebelumnya dengan mengambil sampel dari suatu populasi dan menggunakan kuesioner sebagai alat pengumpulan data yang pokok.

Kecamatan Banjarsari dipilih secara purposif sebagai lokasi penelitian dengan pertimbangan luasnya lahan usahatani kedelai dibandingkan dengan kecamatan lainnya di Kabupaten Ciamis. Petani yang melaksanakan usahatani kedelai di Kecamatan Banjarsari sebanyak 3.533 orang. Ukuran sampel penelitian dihitung dengan menggunakan rumus Slovin (Amirin, 2011) dengan marjin kesalahan $10 \%$, dan diperoleh ukuran sampel penelitian sebanyak 97 petani.

Kemudian dilanjutkan dengan perhitungan ukuran sampel secara Proportionate Stratified Random Sampling, digunakan rumus alokasi proporsional (Daniel, 2003), terdiri dari 31 orang petani lahan luas, 51 orang petani lahan sedang dan 15 orang petani lahan sempit.

Data yang digunakan dalam penelitian ini terdiri atas data primer dan sekunder. Pengumpulan data primer melalui wawancara dengan menggunakan kuesioner yang telah dipersiapkan sebelumnya. Data primer yang dikumpulkan terdiri atas karakteristik individu petani dan data input serta output usahatani kedelai pada musim tanam 2013. Sedangkan data sekunder diperoleh melalui penelusuran pustaka maupun publikasi dari dinas atau instansi terkait.

Variabel-variabel yang digunakan dalam penelitian ini adalah :

- Efisiensi produksi yaitu tercapainya produksi yang optimum dengan sumber daya yang ada.

- lahan $\left(\mathrm{X}_{1}\right)$ adalah luas lahan yang diusahakan oleh petani untuk melakukan usahatani kedelai, diukur dalam satuan hektar (ha),

- Benih $\left(X_{2}\right)$ diukur dalam satuan kilogram $(\mathrm{kg})$,

- Pupuk Urea $\left(X_{3}\right)$, Pupuk SP-36 $\left(X_{4}\right)$, Pupuk $\mathrm{KCL}\left(\mathrm{X}_{5}\right)$ diukur dalam satuan kilogram $(\mathrm{kg})$,

- Pupuk Organik atau Pupuk Kandang $\left(\mathrm{X}_{6}\right)$ adalah pupuk yang digunakan oleh petani yang berasal dari kotoran hewan ternak (sapi, ayam dan kambing), diukur dalam satuan kilogram $(\mathrm{kg})$,

- Pestisida $\left(X_{7}\right)$ diukur dalam satuan liter (ltr),
- Tenaga Kerja $\left(\mathrm{X}_{8}\right)$ diukur dalam satuan Hari Orang Kerja (HOK).

Untuk mengetahui pengaruh penggunaan faktor-faktor produksi usahatani kedelai digunakan analisis fungsi produksi CobbDouglass:

$$
Y=a X_{1}^{b 1} X_{2}^{b 2} \ldots X_{i}^{b i} \ldots X_{n}^{b n} . . e^{u}
$$

Untuk memudahkan pendugaan dinyatakan dengan mengubah bentuk linier berganda setelah melogaritmakan persamaan-persamaan tersebut.

$$
\underset{b_{i} \log X_{i}+\log e^{u}}{\log a+b_{1} \log X_{1}+b_{2} \log X_{2}+\ldots+}
$$

Pendugaan parameter regresi linier berganda tersebut dilakukan dengan menggunakan program SPSS versi 17.

Setelah diperoleh koefisien regresi, maka dilakukan uji $\mathrm{F}$ (secara simultan) dan uji $\mathrm{t}$ (secara parsial).

Untuk menganalisis efisiensi teknis dilakukan melalui pendekatan Stochastic Production Frontiers dengan metode Maximum Likelihood Estimated (MLE) dan komputasinya menggunakan program Frontier Versi 41, dengan bentuk umum spesifikasi model (Elys Fauzyah, 2007) :

$$
\mathrm{Qi}=\mathrm{Q}\left(X_{\mathrm{ki}} \beta\right) \mathrm{e}^{\mathrm{ei}}
$$

Model yang digunakan dalam penelitian ini adalah :

$$
\text { Ln } Y i=\beta_{0}+\sum_{i}^{n} \beta_{\mathrm{k}} \operatorname{Ln} X_{\mathrm{ki}}+\epsilon_{\mathrm{i}}
$$

Dimana : $\epsilon_{\mathrm{i}}=\mathrm{v}_{\mathrm{i}}-\mathrm{u}_{\mathrm{i}}$

Yi = Produksi kedelai (kilogram)

$\mathrm{X}=$ Faktor-faktor produksi usahatani yang diteliti.

$\beta_{0} \quad=$ Intercept

Efisiensi penggunaan faktor produksi secara ekonomis dianalisa dengan menggunakan efisiensi harga. Perhitungan efisiensi harga berdasarkan penggunaan teknik fungsi produksi Cobb-Douglass adalah :

$$
\begin{aligned}
& \text { bi.Y.Py }=\text { PXi Xi } \\
& \text { NPMXi }=\text { PXi atau } \frac{N P M x_{i}}{P x_{i}}=1
\end{aligned}
$$




\section{AIMBAR \\ Agribisnis}

ISSN 2460-4321

Volume 1 • Nomor 2 • Januari 2016

Dimana :

$$
\begin{array}{ll}
\mathrm{bi} & =\text { elastisitas produksi } \\
\mathrm{Y} & =\text { output } \\
\mathrm{X} & =\text { input } \\
\mathrm{Py} & =\text { harga output } \\
\mathrm{PXi} & =\text { harga input }
\end{array}
$$

Dengan kriteria hasil perhitungan, Jika :

- NPMXi/PXi = 1, artinya penggunaan faktorfaktor produksi sudah efisien.

- NPMXi/PXi > 1, artinya penggunaan faktorfaktor produksi belum efisien atau perlu ditambah.

- NPMXi/PXi < 1, artinya penggunaan faktorfaktor produksi tidak efisien atau harus dikurangi.

\section{HASIL DAN PEMBAHASAN \\ Pengaruh Penggunaan Faktor-faktor Produksi}

- Pada lahan luas

Analisis faktor-faktor yang berpengaruh terhadap produksi kedelai pada lahan luas diperoleh nilai koefisien determinasi $\left(\mathrm{R}^{2}\right)$ sebesar 0,9999. Hal ini menunjukkan bahwa variasi variabel produksi (Y) sebesar 99,99 persen dapat diterangkan oleh variabel-variabel yang dimasukan dalam model sedangkan sisanya dipengaruhi oleh variabel lain yang tidak dimasukan kedalam model.

Nilai F-hitung sebesar 145.636 sedangkan nilai F-tabel pada taraf nyata 1 persen sebesar 3,173, hal ini menunjukkan bahwa seluruh variabel bebas berpengaruh sangat nyata (highly significant) terhadap produksi kedelai.

Secara parsial variabel lahan berpengaruh sangat nyata (highly significant) terhadap produksi pada taraf nyata 1 persen dan benih, tenaga kerja berpengaruh nyata (significant) pada taraf nyata 5 persen, pengaruh positif ditunjukkan oleh koefisien lahan, benih, KCL, organik dan pestisida serta pengaruh negatif ditunjukkan oleh koefisien urea, SP-38 dan tenaga kerja. Sedangkan urea, SP-36, KCL, organik dan pestisida tidak berpengaruh terhadap produksi usahatani kedelai.

- Pada lahan sedang

Analisis faktor-faktor yang berpengaruh terhadap produksi kedelai pada lahan sedang diperoleh nilai koefisien determinasi $\left(\mathrm{R}^{2}\right)$ sebesar 0,9996. Hal ini menunjukkan bahwa variasi variabel produksi (Y) sebesar 99,96 persen dapat diterangkan oleh variabel-variabel yang dimasukan dalam model sedangkan sisanya dipengaruhi oleh variabel lain yang tidak dimasukan kedalam model.

Nilai F-hitung sebesar 14.919 sedangkan nilai F-tabel pada taraf nyata 1 persen sebesar 2,678 hal ini menunjukkan bahwa secara simultan variabel bebas $\left(\mathrm{X}_{\mathrm{i}}\right)$ berpengaruh sangat nyata (highly significant) terhadap produksi (Y).

Secara parsial variabel lahan berpengaruh sangat nyata (highly significant) terhadap produksi pada taraf nyata 1 persen dan benih, tenaga kerja berpengaruh nyata (significant) pada taraf nyata 5 persen. pengaruh positif ditunjukkan oleh koefisien lahan, benih, urea, KCL dan organik serta pengaruh negatif ditunjukkan oleh koefisien SP-36, pestisida dan tenaga kerja. Sedangkan urea, SP-36, KCL, organik dan pestisida tidak berpengaruh terhadap produksi.

- Pada lahan sempit

Analisis faktor-faktor yang berpengaruh terhadap produksi kedelai pada lahan sempit diperoleh nilai koefisien determinasi $\left(\mathrm{R}^{2}\right)$ sebesar 0,9999. Hal ini menunjukkan bahwa variasi variabel produksi (Y) sebesar 99,99 variabel-variabel yang dimasukan dalam model sedangkan sisanya dipengaruhi oleh variabel lain yang tidak dimasukan kedalam model.

Nilai F-hitung sebesar 418.161 sedangkan nilai F-tabel pada taraf nyata 1 persen sebesar 2,977 hal ini menunjukkan bahwa secara simultan variabel bebas $\left(\mathrm{X}_{\mathrm{i}}\right)$ berpengaruh sangat nyata (highly significant) terhadap produksi (Y).

Secara parsial variabel lahan, urea dan KCL berpengaruh sangat nyata (highly significant) terhadap produksi pada taraf nyata 1 persen dan tenaga kerja berpengaruh nyata (significant) pada taraf nyata 5 persen, pengaruh positif terlihat dari tanda positif pada koefisien lahan, benih, SP-36, KCL pestisida dan tenaga kerja serta pengaruh negatif terlihat dari tanda negatif pada koefisien urea dan organik. Sedangkan benih, SP-36, organik dan pestisida tidak berpengaruh nyata (non significant) terhadap produksi. 


\section{Estimasi Efisiensi Teknis dan Ekonomis Usahatani Kedelai \\ (Glycine max L.) Pada Lahan Sawah \\ HENDAR NURYAMAN}

\section{Efisiensi Penggunaan Faktor-faktor Produksi \\ Secara Teknis}

- Pada lahan luas

Hasil pendugaan fungsi produksi frontier dengan menggunakan komputasi program Frontier versi 4.1 pada lahan luas disajikan pada Tabel 1 .

Tabel 1. Hasil Pendugaan Parameter Fungsi Produksi Frontier Stokastik pada Lahan Luas

\begin{tabular}{|l|r|r|r|}
\hline Parameter & \multicolumn{1}{|c|}{$\begin{array}{c}\text { Nilai } \\
\text { Dugaan }\end{array}$} & $\begin{array}{c}\text { Standar } \\
\text { Error }\end{array}$ & \multicolumn{1}{c|}{ t-rasio } \\
\hline$\left(\beta_{0}\right)$ & 3,2171 & 0,0844 & 38,1214 \\
$\left(\beta_{1}\right)$ & $0,9629 *$ & 0,0473 & 20,3675 \\
$\left(\beta_{2}\right)$ & $0,0660^{*}$ & 0,0280 & 2,3607 \\
$\left(\beta_{3}\right)$ & $-0,0068$ & 0,0145 & $-0,4675$ \\
$\left(\beta_{4}\right)$ & 0,0080 & 0,0210 & 0,3816 \\
$\left(\beta_{5}\right)$ & 0,0181 & 0,0270 & 0,6699 \\
$\left(\beta_{6}\right)$ & $0,0156^{*}$ & 0,0072 & 2,1586 \\
$\left(\beta_{7}\right)$ & $-0,0002$ & 0,0012 & $-0,1880$ \\
$\left(\beta_{8}\right)$ & $-0,0633^{*}$ & 0,0310 & $-2,0431$ \\
\hline$\sigma^{2}$ & & & \\
Gamma & \multicolumn{2}{|c|}{0,9842} \\
Log lf & 0,8400 \\
LR & 183,2473 \\
\hline
\end{tabular}

$*$ = signifikan pada $\alpha=5$ persen

Hasil fungsi produksi frontier stokastik menunjukkan bahwa nilai gamma sebesar 0,84 . Jadi, galat satu sisi (one-sided error) ui mendominasi sebaran galat simetris dari vi. Hal ini juga didukung oleh nilai LR Test of the onesided error yang sangat nyata (lebih dari 1). Ini menunjukkan bahwa hampir semua variasi dalam keluaran dari produksi frontier dapat dianggap sebagai akibat dari tingkat pencapaian efisiensi teknis yang berkaitan dengan persoalan manajerial dalam pengelolaan usahatani. Penggunaan faktor produksi lahan, benih, organik dan tenaga kerja berpengaruh nyata terhadap produksi pada usahatani kedelai.

Tabel 2. Rata-rata tingkat efisiensi teknis pada Lahan Luas

\begin{tabular}{|c|c|c|}
\hline No & Parameter & Nilai \\
\hline 1. & Rata-rata & 0,9993 \\
\hline 2. & Standar Deviasi & 0,0005 \\
\hline
\end{tabular}

Pada tabel 2 menunjukkan rata-rata tingkat efisiensi teknis yang dicapai petani dalam melaksanakan usahatani kedelai adalah 0,9993. Hal ini menunjukkan bahwa rata-rata petani telah mampu mencapai efisien secara teknis dalam melaksanakan usahatani kedelai. Dengan kata lain, pada usahatani kedelai tersebut telah dapat dicapai tingkat produksi maksimum dengan penggunaan faktor-faktor produksi yang ada.

Akan tetapi dari 31 petani, terdapat beberapa petani yang memiliki efisiensi teknis dibawah rata-rata sebanyak 8 orang, yaitu petani nomor 5, 6, 7, 11, 20, 28, 29 dan 30 . Pada petani golongan ini diperlukan pelaksanaan kegiatan penyuluhan yang lebih intensif agar petani dapat meningkatkan efisiensi teknis usahataninya.

- Pada lahan sedang

Hasil pendugaan fungsi produksi frontier dengan menggunakan komputasi program Frontier versi 4.1 pada lahan sedang disajikan pada Tabel 3.

Tabel 3. Hasil Pendugaan Parameter Fungsi Produksi Frontier Stokastik pada Lahan Sedang

\begin{tabular}{|l|r|r|r|}
\hline Parameter & \multicolumn{1}{|c|}{$\begin{array}{c}\text { Nilai } \\
\text { Dugaan }\end{array}$} & $\begin{array}{c}\text { Standar } \\
\text { Error }\end{array}$ & \multicolumn{1}{c|}{ t-rasio } \\
\hline$\left(\beta_{0}\right)$ & 2,5860 & 0,4020 & 6,4331 \\
$\left(\beta_{1}\right)$ & $0,9098^{*}$ & 0,1696 & 5,3648 \\
$\left(\beta_{2}\right)$ & $0,0847^{*}$ & 0,0413 & 2,0498 \\
$\left(\beta_{3}\right)$ & 0,0308 & 0,0221 & 1,3932 \\
$\left(\beta_{4}\right)$ & $-0,0463$ & 0,0653 & $-0,7093$ \\
$\left(\beta_{5}\right)$ & 0,0157 & 0,0512 & 0,3059 \\
$\left(\beta_{6}\right)$ & 0,1271 & 0,1446 & 0,8787 \\
$\left(\beta_{7}\right)$ & $-0,0079$ & 0,0123 & $-0,6440$ \\
$\left(\beta_{8}\right)$ & $-0,1072^{*}$ & 0,0449 & $-2,3898$ \\
\hline$\sigma^{2}$ & 0,2103 & & \\
Gamma & 0,4100 & & \\
Log lf & 209,9881 & \\
LR & 0,0308 & \\
\hline
\end{tabular}

$*$ = signifikan pada $\alpha=5$ persen

Hasil estimasi fungsi produksi frontier stokastik menunjukkan bahwa nilai gamma sebesar 0,41. Jadi, galat satu sisi (one-sided error) ui tidak mendominasi sebaran galat simetris dari vi. Hal ini juga didukung oleh nilai LR Test of the one-sided error yang kurang dari 1. Penggunaan faktor produksi lahan, benih dan tenaga kerja berpengaruh nyata terhadap produksi pada usahatani kedelai.

Tabel 4. Rata-rata tingkat efisiensi teknis pada Lahan Sempit

\begin{tabular}{|c|c|c|}
\hline No & Parameter & Nilai \\
\hline 1. & Rata-rata & 0,9977 \\
\hline 2. & Standar Deviasi & 0,0008 \\
\hline
\end{tabular}




\section{AIMBAR Agribisnis}

ISSN 2460-4321

Volume 1・ Nomor 2 • Januari 2016

Pada tabel 4 menunjukkan rata-rata tingkat efisiensi teknis yang dicapai petani dalam melaksanakan usahatani kedelai adalah 0,9977. Hal ini menunjukkan bahwa rata-rata petani telah mampu mencapai efisiensi teknis dalam melaksanakan usahatani kedelai. Dengan kata lain, pada usahatani kedelai tersebut telah dapat dicapai tingkat produksi maksimum dengan penggunaan faktor-faktor produksi yang ada. Akan tetapi dari jumlah 51 petani, terdapat beberapa petani yang memiliki efisiensi teknis dibawah rata-rata sebanyak 13 orang, yaitu petani nomor $3,4,7,10,12,14,18,21,24,26$, 28, 30 dan 31. Pada petani golongan ini diperlukan pelaksanaan kegiatan penyuluhan yang lebih intensif agar petani dapat meningkatkan efisiensi teknis usahataninya.

- Pada lahan sempit

Hasil pendugaan fungsi produksi frontier dengan menggunakan komputasi program Frontier versi 4.1 pada lahan sempit disajikan pada Tabel 5.

Tabel 5. Hasil Pendugaan Parameter Fungsi Produksi Frontier Stokastik pada Lahan Sempit

\begin{tabular}{|l|r|r|r|}
\hline Parameter & \multicolumn{1}{|c|}{$\begin{array}{c}\text { Nilai } \\
\text { Dugaan }\end{array}$} & $\begin{array}{c}\text { Standard } \\
\text { Error }\end{array}$ & \multicolumn{1}{c|}{ t-rasio } \\
\hline$\left(\beta_{0}\right)$ & 3,1304 & 0,0002 & 0,1420 \\
$\left(\beta_{1}\right)$ & $1,0000^{*}$ & 0,8550 & 0,1170 \\
$\left(\beta_{2}\right)$ & 0,1620 & 0,3750 & 0,0431 \\
$\left(\beta_{3}\right)$ & $-0,1080$ & 0,5200 & $-0,2076$ \\
$\left(\beta_{4}\right)$ & $-0,2550$ & 0,6010 & $-0,0425$ \\
$\left(\beta_{5}\right)$ & 0,1760 & 0,7230 & 0,2433 \\
$\left(\beta_{6}\right)$ & $-0,3910$ & 0,9020 & $-0,4339$ \\
$\left(\beta_{7}\right)$ & 0,4890 & 0,1920 & 0,2554 \\
$\left(\beta_{8}\right)$ & 0,4560 & 0,3020 & 0,1508 \\
\hline$\sigma^{2}$ & 0,2076 & & \\
Gamma & 0,9500 & \\
Log lf & 207,1519 & \\
LR & 4,8999 & \\
\hline
\end{tabular}

* = signifikan pada $\alpha=5$ persen

Hasil estimasi fungsi produksi frontier stokastik menunjukkan bahwa nilai gamma mendekati 1. Jadi, galat satu sisi (one-sided error) ui mendominasi sebaran galat simetris dari vi. Hal ini juga didukung oleh nilai LR Test of the one-sided error yang sangat nyata (lebih dari 1). Ini menunjukkan bahwa hampir semua variasi dalam keluaran dari produksi frontier dapat dianggap sebagai akibat dari tingkat pencapaian efisiensi teknis yang berkaitan dengan persoalan manajerial dalam pengelolaan usahatani. Pada lahan sempit, hanya faktor produksi lahan $(1,0000)$ berpengaruh nyata terhadap produksi pada usahatani kedelai.

Tabel 6. Rata-rata tingkat efisiensi teknis pada Lahan Sempit

\begin{tabular}{|c|c|r|}
\hline No & Parameter & \multicolumn{1}{c|}{ Nilai } \\
\hline 1. & Rata-rata & $9.999997 \mathrm{E}-01$ \\
\hline 2. & Standar Deviasi & $2,705 \mathrm{E}-07$ \\
\hline
\end{tabular}

Pada tabel 6 menunjukkan rata-rata tingkat efisiensi teknis yang dicapai petani dalam melaksanakan usahatani kedelai adalah 0,9998. Hal ini menunjukkan bahwa rata-rata petani telah mampu mencapai efisiensi teknis dalam melaksanakan usahatani kedelai. Dengan kata lain, pada usahatani kedelai tersebut telah dapat dicapai tingkat produksi maksimum dengan penggunaan faktor-faktor produksi yang ada. Akan tetapi dari jumlah 15 petani, terdapat beberapa petani yang memiliki efisiensi teknis dibawah rata-rata, yaitu petani nomor 2, 4, 5, 6, 7 dan 11. Pada petani golongan ini diperlukan pelaksanaan kegiatan penyuluhan yang lebih intensif agar petani dapat meningkatkan efisiensi teknis usahataninya.

\section{Efisiensi Penggunaan Faktor-faktor Produksi Secara Ekonomis}

- Pada lahan luas

Hasil perhitungan pada lahan luas menunjukkan bahwa perbandingan Nilai Produk Marjinal (NPM) dengan harga faktor produksi (Pxi) penggunaan lahan, benih dan pupuk KCL mempunyai perbandingan NPM/PXi > 1 hal ini menyatakan bahwa penggunaan faktor produksi tersebut pada usahatani kedelai belum efisien, artinya penggunaan faktor-faktor produksi tersebut dari sisi ekonomis masih kurang sehingga perlu ditambah. Penambahan penggunaan faktor produksi tersebut akan menyebabkan tercapainya tingkat efisiensi ekonomis pada usahatani kedelai.

Sedangkan penggunaan pupuk urea, pupuk SP-36, pupuk organik, pestisida dan untuk tenaga kerja mempunyai perbandingan $\mathrm{NPM} / \mathrm{PXi}<1$ maka penggunaan faktor produksi tersebut tidak efisien, artinya dari sisi ekonomis terlalu berlebihan sehingga perlu dikurangi. Pengurangan faktor produksi tersebut akan menyebabkan tercapainya tingkat 
efisiensi secara ekonomis pada usahatani kedelai.

Tabel 7. Efisiensi Penggunaan Faktor Produksi Usahatani Kedelai pada Lahan Luas

\begin{tabular}{|c|l|r|l|}
\hline No & \multicolumn{1}{|c|}{$\begin{array}{c}\text { Faktor } \\
\text { Produksi }\end{array}$} & $\begin{array}{c}\text { Nilai } \\
\text { Efisiensi } \\
\text { Ekonomis }\end{array}$ & Keterangan \\
\hline 1. & Lahan $\left(\mathrm{X}_{1}\right)$ & 59,590 & Belum Efisien \\
2. & Benih $\left(\mathrm{X}_{2}\right)$ & 1,690 & Belum Efisien \\
3. & Urea $\left(\mathrm{X}_{3}\right)$ & $-0,647$ & Tidak Efisien \\
4. & SP-36 $\left(\mathrm{X}_{4}\right)$ & $-0,202$ & Tidak Efisien \\
5. & KCL $\left(\mathrm{X}_{5}\right)$ & 1,134 & Belum Efisien \\
6. & Organik $\left(\mathrm{X}_{6}\right)$ & 0,415 & Tidak Efisien \\
7. & Pestisida $\left(\mathrm{X}_{7}\right)$ & $-0,037$ & Tidak Efisien \\
8. & TK $\left(\mathrm{X}_{8}\right)$ & $-0,622$ & Tidak Efisien \\
\hline
\end{tabular}

- Pada lahan sedang

Hasil perhitungan pada lahan sedang menunjukkan bahwa perbandingan Nilai Produk Marjinal (NPM) dengan harga faktor produksi (Pxi) penggunaan lahan, urea dan organik mempunyai perbandingan NPM/PXi > 1 maka penggunaan faktor produksi lahan, urea dan organik pada usahatani kedelai belum efisien, artinya penggunaan faktor produksi tersebut dari sisi ekonomis masih kurang sehingga perlu ditambah. Penambahan penggunaan faktor produksi tersebut akan menyebabkan tercapainya tingkat efisiensi ekonomis pada usahatani kedelai.

Sedangkan penggunaan benih, pupuk SP36, pupuk KCL, pestisida dan tenaga kerja mempunyai perbandingan NPM/PXi $<1$ maka penggunaan faktor produksi tersebut tidak efisien, artinya dari sisi ekonomis terlalu berlebihan sehingga perlu dikurangi. Pengurangan penggunaan faktor produksi tersebut akan menyebabkan tercapainya tingkat efisiensi secara ekonomis pada usahatani kedelai.

Tabel 8. Efisiensi Penggunaan Faktor Produksi Usahatani Kedelai pada Lahan Sedang

\begin{tabular}{|c|l|r|l|}
\hline No & \multicolumn{1}{|c|}{$\begin{array}{c}\text { Faktor } \\
\text { Produksi }\end{array}$} & $\begin{array}{c}\text { Nilai } \\
\text { Efisiensi } \\
\text { Ekonomis }\end{array}$ & Keterangan \\
\hline 1. & Lahan $\left(\mathrm{X}_{1}\right)$ & 19,870 & Belum Efisien \\
2. & Benih $\left(\mathrm{X}_{2}\right)$ & 0,677 & Tidak Efisien \\
3. & Urea $\left(\mathrm{X}_{3}\right)$ & 3,257 & Belum Efisien \\
4. & SP-36 $\left(\mathrm{X}_{4}\right)$ & $-2,197$ & Tidak Efisien \\
5. & KCL $\left(\mathrm{X}_{5}\right)$ & 0,902 & Tidak Efisien \\
6. & Organik $\left(\mathrm{X}_{6}\right)$ & 2,153 & Belum Efisien \\
7. & Pestisida $\left(\mathrm{X}_{7}\right)$ & $-0,246$ & Tidak Efisien \\
8. & TK $\left(\mathrm{X}_{8}\right)$ & $-0,421$ & Tidak Efisien \\
\hline
\end{tabular}

- Pada lahan sempit

Hasil perhitungan pada lahan sempit menunjukkan bahwa perbandingan Nilai Produk Marjinal (NPM) dengan harga faktor produksi (Pxi) penggunaan lahan mempunyai perbandingan NPM/PXi > 1 maka penggunaan faktor produksi lahan pada usahatani kedelai belum efisien, artinya penggunaan faktor produksi tersebut dari sisi ekonomis masih kurang sehingga perlu ditambah. Penambahan penggunaan faktor produksi tersebut akan menyebabkan tercapainya tingkat efisiensi ekonomis pada usahatani kedelai.

Sedangkan penggunaan benih, urea, SP-36, KCL, organik, pestisida dan tenaga kerja mempunyai perbandingan NPM/PXi $<1$ maka penggunaan faktor produksi tersebut tidak efisien, artinya dari sisi ekonomis terlalu penggunaan faktor produksi tersebut berlebihan sehingga perlu dikurangi. Pengurangan penggunaan faktor produksi tersebut akan menyebabkan tercapainya tingkat efisiensi secara ekonomis pada usahatani kedelai.

Tabel 9. Efisiensi Penggunaan Faktor Produksi Usahatani Kedelai pada Lahan Sedang

\begin{tabular}{|c|l|r|l|}
\hline No & \multicolumn{1}{|c|}{$\begin{array}{c}\text { Faktor } \\
\text { Produksi }\end{array}$} & $\begin{array}{c}\text { Nilai } \\
\text { Efisiensi } \\
\text { Ekonomis }\end{array}$ & Keterangan \\
\hline 1. & Lahan $\left(\mathrm{X}_{1}\right)$ & 42,096 & Belum Efisien \\
2. & Benih $\left(\mathrm{X}_{2}\right)$ & 0,043 & Tidak Efisien \\
3. & Urea $\left(\mathrm{X}_{3}\right)$ & $-0,846$ & Tidak Efisien \\
4. & SP-36 $\left(\mathrm{X}_{4}\right)$ & 0,445 & Tidak Efisien \\
5. & KCL $\left(\mathrm{X}_{5}\right)$ & 0,806 & Tidak Efisien \\
6. & Organik $\left(\mathrm{X}_{6}\right)$ & $-0,946$ & Tidak Efisien \\
7. & Pestisida $\left(\mathrm{X}_{7}\right)$ & 0,018 & Tidak Efisien \\
8. & TK $\left(\mathrm{X}_{8}\right)$ & 0,022 & Tidak Efisien \\
\hline
\end{tabular}

Estimasi tingkat penggunaan faktor-fakor produksi untuk mencapai kondisi yang optimal dihitung dengan menggunakan perbandingan antara penggunaan faktor produksi secara aktual dengan harga faktor produksinya, menunjukkan :

- Pada lahan luas

Hasil perhitungan reorganisasi penggunaan faktor produksi untuk mencapai kondisi optimal pada lahan luas adalah : lahan $(+44,240)$, benih $(+25,410)$, urea $(-15,542)$, SP-36 $(-39,556)$, KCL $(+8,831)$, organik $(-249,208)$, pestisida ($1,271)$ dan tenaga kerja $(-20,894)$. 


\section{AIMBAR \\ Agribisnis \\ ISSN 2460-4321}

Volume 1・ Nomor 2・ Januari 2016

- Pada lahan sedang

Hasil perhitungan reorganisasi penggunaan faktor produksi untuk mencapai kondisi optimal pada lahan sedang adalah : lahan $(+14,471)$, benih $(-8,814)$, urea $(+0,609)$, SP-36 $(-2,549)$, KCL $(-5,365)$, organik $(+55,959)$, pestisida ($0,120)$ dan tenaga kerja $(-11,227)$. dan

- Pada lahan sempit

Hasil perhitungan reorganisasi penggunaan faktor produksi untuk mencapai kondisi optimal pada lahan sempit adalah : lahan $(+1,375)$, benih $(-1,928)$, urea $(-0,416)$, SP-36 $(-1,404)$, KCL $(-0,754)$, organik $(-1,220)$, pestisida ($0,376)$ dan tenaga kerja $(-2,741)$.

\section{KESIMPULAN}

1. Secara teknis, faktor produksi lahan, benih dan tenaga kerja berpengaruh terhadap produksi pada lahan luas dan lahan sedang, sedangkan pupuk organik hanya berpengaruh pada lahan luas. Pada lahan sempit, hanya faktor produksi lahan yang berpengaruh terhadap produksi. Secara ekonomis, analisis simultan variabel yang diamati baik itu pada lahan luas, sedang maupun pada lahan sempit berpengaruh nyata terhadap produksi. Sedangkan secara parsial pada lahan luas dan lahan sedang variable lahan, benih dan tenaga kerja berpengaruh nyata. Sedangkan pada lahan sempit, variabel lahan, urea, KCL dan tenaga kerja berpengaruh nyata terhadap produksi usahatani kedelai.

2. Secara teknis pada lahan luas, sedang dan sempit sudah mendekati tingkat yang efisien. Secara ekonomis pada lahan luas, sedang dan sempit tidak ada faktor produksi yang tepat efisien atau NPMXi/PXi=1. Faktor-faktor produksi kebanyakan berada pada kondisi yang tidak efisien baik itu pada lahan luas, sedang maupun sempit, dengan kata lain penggunaannya terlalu berlebihan sehingga perlu dikurangi.

3. Estimasi penggunaan lahan baik pada lahan luas, sedang dan sempit perlu ditambah. Benih perlu ditambah pada lahan luas, Urea perlu ditambah pada lahan sedang, Pupuk KCL perlu ditambah pada lahan luas dan Pupuk organik perlu ditambah pada lahan sedang. Sedangkan sisanya perlu dikurangi baik itu pada lahan luas, sedang dan sempit.

\section{DAFTAR PUSTAKA}

Abdul G. Tahir .2010. Analisis Efisiensi Produksi Sistem Usahatani Kedelai di Sulawesi Selatan. Jurnal Agro Ekonomi, Volume 28 No.2, Oktober 2010 : 133 - 15

Amirin, Tatang M. 2011. "Populasi dan sampel penelitian 4: Ukuran sampel rumus Slovin". Tatang manguny. wordpress.com.

Badan Pusat Statistik (BPS). 2010. Statistik Daerah Kabupaten Ciamis 2010. CV Bahtiar. Tasikmalaya

Daniel, M. 2003. Metode Penelitian Sosial Ekonomi. Bumi Aksara. Jakarta.

Elys Fauziyah .2007. Analisis Usahatani Kedelai di Desa Sukosari Kecamatan Gondanglegi. Jurnal EMBRYO Vol. 4 No. 1 dengan ISSN 0216-0188.

Juwono, T. A. 2009. Jenis Metode Penelitian. Diktat Mata Kuliah MP-PR Fikom. Universitas Mercubuana. Jakarta

Marwoto dan Y. Hilman. 2005. Teknologi kacang-kacangan dan umbi-umbian mendukung ketahanan pangan. Kinerja Balitkabi 2003-2004. Balitkabi. $20 \mathrm{hlm}$.

Sahara, D dan Sahardi. 2005. Efisiensi Faktor Produksi Lada pada Pola Usahatani Integrasi dan Pola Tradisional di Sulawesi Tenggara. Balai Pengkajian Teknologi Pertanian Sulawesi Tenggara Jln. M. Yamin No 89 Puwatu-Kendari.

Soekartawi 2003. Dasar-dasar Ekonomi Produksi "Teori dan Aplikasi". Raja Grafindo Persada. Jakarata

Sri Sulastri. 2011. Analisis Usahatani Kedelai (Glycine max L.) yang Berkelanjutan di Kecamatan Sukorejo Kabupaten Ponorogo. Program Magister Pengelolaan Sumberdaya Lingkungan Dan Pembangunan Pasca Sarjana Universitas Brawijaya Malang, Fakultas Pertanian, Universitas Brawijaya Malang

Sudjana. 2002. Teknik Analisis Regresi dan Korelasi bagi Para Peneliti. Tarsito. Bandung

Suratiyah, K. 2006. Ilmu Usahatani. Penebar Swadaya. Jakarta.

Wijaya, T. 2009. Analisis Data Penelitian Menggunakan SPSS. Universitas Atma Jaya Yogyakarta. Yogyakarta 